\title{
Professional Training of the Tatar Composers in the 1930s of the XX Century
}

\author{
Liliya I. Salikhova*1, Albert N. Asadullin² \\ ${ }^{1}$ Kazan Federal University, Institute of Philology and Intercultural Communication, \\ ${ }^{2}$ Herzen State Pedagogical University of Russia, The Institute of Music, Theatre and Choreography \\ ${ }^{* 1}$ Email: Lilasalihova82@mail.ru,Contact: 89655852662
}

Received: $21^{\text {st }}$ October 2017 Accepted: $16^{\text {th }}$ November 2017, Published: 31 ${ }^{\text {st }}$ December 2017

\begin{abstract}
The problems of training composers of the national republics of the USSR came to the fore in the 1920s and 1930s of the XX century, when the accelerated formation of national professional cultures began. Professional training of national composers in the 1930s was largely undertaken by the capital higher educational institutions, in particular by the Moscow State Conservatory. It was during this period that the national studios and departments with composer groups were opened in it. This article highlights the process of teaching Tatar composers (S. Saydashev, M. Muzafarov, Dzh. Fayzi, F. Yaarullin, Z. Habibullin, etc.) in the Moscow Conservatory within the framework of the working faculty, ethnographic department, as well as the Tatar opera studio. We revealed the issues of educational tactics of the curator and teacher of the composer group G.I. Litinsky, who was looking for new, nationally oriented methods of teaching. We describe the creative problems encountered by both teachers and students. It is outlined the genre range of the composers creativity. The author of this article analyzes the positive and negative aspects of the educational process aimed at achieving academic level professionalism by the European composers.

When studying the problem posed, the author used a complex approach combining the features of historical and analytical methods of research, introduced new, documented facts into scientific circulation. The article is an attempt to build the fullest possible picture of the phenomenon as a basis for a broad scientific interpretation of musical education of national composers in the Soviet era.

The materials of this article can be used in the training courses on the history of native and Tatar musical culture.
\end{abstract}

Keywords: Tatar Composers, Professional Training, 1930s, Tatar Opera Studio, Moscow Conservatory, Teaching Methods.

\section{Introduction}

The musical culture of the "young" national republics of the USSR was at the epicenter of the most complex transformations in the 1930s. In this period, the problem of professional training of national composers, just starting to master the major academic genres of the
European tradition, is of independent scientific interest. The analysis of the training process of Tatar composers in the Tatar Opera Studio at the Moscow State Conservatory outlines all the difficulties faced by the teachers and students, which enable us to more deeply understand the problems of forming the composer schools of the national republics of the USSR.

The issues of musical education and enlightenment in the Republic of Tatarstan in the first half of the XX century have recently attracted the attention of scientists in the pages of various journals. There are such authors as N. Egorova, R. Samigullina, Z. Yavgildina [1], L. Faizrakhmanova, E. Kovrikova [2], S. Karkina, L. Fajzrahmanova [3], Y. Martynova, D. Martynov [4]. In addition, there is an active interest in the work of individual Tatar composers. There are such researchers as R. Khurmatullina, I. Salpykova [5], E. Kovrikova, N. Nurgayanova [6], A. Salihov, V. DulatAleev [7]. The problems of forming professionalism of the composers of the Tatar musical culture and mastering the new genres of the European tradition are touched upon in the works of A. Maklygin [8, 9].

However, the issues of training Tatar composers have not yet become the object of a special in-depth study in the 1930s. In this article, the author makes an attempt to fill some "white spots" in the history of the Tatar musical culture. A historical retrospective on the problem of training composers, highlight of creative and methodological problems arising in the training process, will create the most complete picture of the musical education of national composers in the Soviet era.

The materials of this article can be used in the training courses on the history of native and Tatar musical culture.

\section{Methods}

When investigating the problem posed, the author relied on a comprehensive approach combining the principle of historicism and system analysis. First of all, the author turned to archival sources, as well as to new researches in the field of musical culture and education of the Republic of Tatarstan, which allowed recreating the most complete picture of that time.

\section{Results}

Cultural transformations in the life of Tataria after the revolution of 1917 marked a number of problems. 


\section{Helix Vol. 8(1): 2363 - 2366}

Despite the appearance of a number of works for the Tatar musical theater, the first national operas "Sania" and "Esche" by S. Gabyashy, G. Almukhametov and V. Vinogradov, the lack of professional compositional culture in Tataria was felt more and more in the second half of the 1920s. The prospective composer youth, not finding the necessary conditions for creative growth in Kazan, continued its education in Moscow.

In those years, the Moscow State Conservatory (MSC) took care of training the national composers. With the creation of national studios and offices in the 1930s within it, the composer preparation for the republics was significantly intensified. A large group of composers gathered together around the Tatar opera studio, which operated from 1934-1938.

Back in the 1920s, the ethnographic department was opened at the Theoretical and Composer Faculty, where the classes were conducted with young composers from the national republics besides the music and ethnographic work. Insufficiency of preparation did not enable them to be accepted into the basic structure of students of the composer faculty. The students studied the principles of folk harmonization, instrumentation, composition, harmony, polyphony and a number of other disciplines related to folk music [10]. Academic genres of European musical culture remained beyond the capabilities of composers, limiting the wide development of the means of composer technology. M. Muzafarov (on a composition class of A.N. Alexandrov) graduated the ethnographic department among the Tatar composers in 1931.In 1934 he was accepted as a conductor in the Tatar opera studio in the class of Professor Yu.M. Timofeev and continued to take the composition classes of A. Aleksandrov.

The musicians from all over the Soviet Union, who showed a penchant for composer creativity, came also to study at the music worker's faculty ("rabfak"), which existed in the MSC in 1929-1935. His goal was to train musicians for admission to the conservatory. The admission was made for all four courses, depending on the availability of relevant data and training. The practical composition lessons at the "rabfak" gave only the most general training and laid the foundation for future studies. In the first 2 courses, the students received only half an hour of composition a week, in the third year (when specialization was conducted) - an hour of composition, as well as a choir for those who tend to create choral compositions [11]. The training began with a theoretical analysis and collective discussion of musical works (melody, harmony, rhythm, texture), mainly choirs of simple form, mass songs. The students who performed well in the analysis were given creative assignments.

From the composition of small musical constructions, music for voice and separate instruments, as well as small ensembles, the composers gradually switched to the creation of works with a thematic deployment with further joining of counterpoint development of thematic elements [12].
In addition to the composition course, the composers mastered harmony, musical literacy, rhythmic, solfeggio, music history, general pianoforte, reading of scores, instrumentation.

Young Tatar composers studied composition for some time with the "rabfak" students of the Moscow State Conservatory: F. Yarullin - B.S. Shekhter (in 19331934), Z. Khabibullin - M.F. Gnesin (in 1934).In 1935, after the worker's faculty abolition, they moved to the Tatar opera studio.N. Zhiganov, who was studying at the Theoretical and Composer Faculty of the MSC in the class of G.I. Litinsky at that time, also closely contacted with the studio.

Thus, Dzh. Fayzi, S. Saydashev, M. Muzafarov were included in the composer group of the studio in 1934. In 1935 Z. Khabibullin and F. Yarullin, in 1936 - M. Latypov and L. Khamidi, in 1937 - H. Abdulmenev entered in it.

The composers had different preparation degrees. Many of the musicians started their professional education as instrumentalists. Dzh. Fayzi had the education limited only to the music school by the piano class and private lessons in composition. Before studying in the studio, S. Saydashev was already popular as a composer and performer in Tataria, however his professional training was not thorough (he did not finish the Kazan musical school in piano class, studied in the Orenburg Eastern musical school on the trumpet class, took private lessons in music theory). Only L. Khamidi graduated from the composer department of the Moscow Musical College (on theory and composition class of Professor B. Yavorsky) before the studio.

The studio students were trained by the teachers of the MSC. G.I. Litinsky, who consulted all the studio composers, was the curator of the composer group. He trained F. Yarullin (who began with B.S. Shekhter), S. Saydashev, Z. Khabibullin (he began to study with M.F. Gnesin). B.S. Shekhter trained Dzh. Fayzi; A.N. Aleksandrov - M. Muzafarov; G.I. Litinsky and E.O. Messner trained M. Latypov and L. Khamidi.

The creative luggage of the composers mainly included the processing of folk songs and their own songs, music for theatrical plays before the studio. The instrumental music was dominated by plays of small forms (for example, march of front-line soldiers for $\mathrm{M}$. Muzafarov's symphonic orchestra, works for violin and piano by F. Yarullin, waltz for pianoforte, overtures to dramatic plays by S. Saydashev, etc.).

The composer curriculum included the following subjects: composition, instrumentation, harmony, polyphony, analysis of musical forms, piano, music history, musical literature. In addition, they also studied general subjects: history, social and political disciplines, Russian language, mathematics. There were also the lectures on opera art [13].

The fruits of intense active study were manifested, first of all, in mastering large musical forms, mastering harmonic means organically combined with a fivestage scale of Tatar traditional music (pentatonic), various techniques of textured technique. 


\section{Helix Vol. 8(1): 2363 - 2366}

The first step towards professionalism for most composers was the processing of folk songs. This genre included a search for a national style of professional Tatar music, worked out the specific patterns of multivoice harmonization, revealed the individual features of the composers' style. Let us dwell on this in more detail.

The existing system of music education in the conservatory did not take into account the specifics of national cultures, the representatives of which were the new students. During the study, the teachers had many questions: what order should be selected to build a training course; how to combine the different aspects of the European oriented learning of the composition with the specifics of national traditions? Pentatonic in this sense was one of the most complex modal systems in terms of its combining with the laws of classical European harmony. It was a completely unfamiliar sphere that focused on the search for a suitable methodology for the musical and creative pedagogy of that time. G.I. Litinsky was one of the key figures in this process. He was clearly aware of the need to search for new teaching methods and, what was also important, "... increasingly discovered the national wealth" [14, p. 201, 235].

Litinsky saw a song as a melodic model and a characteristic form of Tatar culture perception as a starting point in training the Tatar composers. Highlighting the melodic-thematic factor as a universal, affecting all sides of the composition, he paid no less attention to the development of polyphonic techniques, most associated with the melodic-thematic field of creativity.

The second important point is the development of prerequisites for the gradual identification and development of the individual traits of the student. First of all, a teacher drew attention of his students to the specific modal-intonational and metrorhythmic properties of folk melodies as the basis for searching for their style, purity and identity.

By discussing the ways of education of national composers, the conservatory teachers decided to "break" the five-sound intonation with an orientation to the artistic norms of the world musical culture, but, not allowing the complete dissolution of pentatonic in the general European norms and means of musical expression [14, p. 193].So the method contours gradually emerged and the important pedagogical principles were formed.

The problem was in the degree of synthesis, if one took into account how "incompliant" the pentatonic turned out to be at the first attempts to combine it with the common European techniques of compositional technique. When Litinsky offered Zhiganov his version of the thematic work in the first part of the piano sonata, he heard $\phi$ timid remark of the student that it sounded "not in Tatar!". The reason, according to G.I. Litinsky, was in the fact that the organic traits inherent in the student's imagination could not be reconciled with the intrusion of elements of a different nature (major-minor linearism, chromaticity and other 2365 modifications of melodic-thematic details of compositional development) [14, p. 203-204].

However, the necessary "measure of synthesis" was not fully understood by the teacher himself, with his Eurocentric position, which "opened up" new musical worlds in the very process of working with students.

All composers started their creative activity with processing epy Tatar folk songs, as well as creating a large number of songs - the main genre for them in the initial period of training (for example, "Going for berries", "Sing, nightingale" by M. Muzafarov, "Purple rain" by Z. Khabibullin, "Lyrical song" by F. Yarulin and others). The composers also actively wrote choral music (processing folk songs for M. Muzafarov's chorus, choral songs by Z. Khabibullin, L. Khamidi, etc.).In 1937, in connection with the 100th anniversary of the death of Aleksander Pushkin, the Tatar composers wrote a whole series of romances for poetry verses translated into Tatar ("Do not sing, beauty, with me" M. Muzafarov and F. Yarullin translated by A. Erikeya, "Inezilla! I'm here..." by M. Latypov translated by M. Dzhalil, etc.).

The composers also refer to the genre of overtures and suites for folk songs (for example, for the orchestra "Overture on Tatar themes" by M. Muzafarov, "Tatar suite" by M. Latypov, "Dance suite on Tatar themes" by L. Khamidi).

The chamber-instrumental genres were also mastered. Most of them were brought to life by training purposes, although it was during this period when the wellknown "Poem" for violin by Z. Khabibullin and the violoncello sonata by F. Yarullin were written. They deserved recognition and firmly entrenched in the performers' repertoire.

But the main thing for the composers was the opera orientation, as it required a national repertoire for opening the opera theater in the republic. In addition, the opera was perceived as evidence of the social and political growth of the republic. Therefore, all the composers worked on the opera creation, but only such operas as "Deserter" by N. Zhiganov, "To Galiyaban" by M. Muzafarov, and the ballet "Shurale" by F. Yarullin were brought to the end. L.Salikhova wrote in detail about the reasons for the failures over most operas [15].

At the end of 1938, when the studio was liquidated, taking into account the short period of composers training (2-3 years), F. Yarullin, Z. Khabibullin and M. Latypov stayed in Moscow to continue their studiesaccording to the decision of the leadership. L. Khamidi moved to Kazakhstan, and the rest of composers returned to Kazan, where they continued their creative activity.

\section{Discussion}

To date, it becomes obvious that the demands of immediate results from composers have been absurd. One of the main problems in mastering major genres (symphonies, operas, sonatas), built on the processdynamic principles of development, was in fact that the thinking of "composers-melodists" (S. Saydashev, M. 


\section{Helix Vol. 8(1): $2363-2366$}

Muzafarov, Dzh. Fayzi, Z. Khabibullin) balanced on the verge of written and oral professionalism [8]. Musicians gravitated toward improvisational ways of working with material, to verbally performing nature of composing music. For the same reason, the disciplines that required written methods of mastering the material (harmony, polyphony, instrumentation) caused them great difficulties. So, for example, S. Saydashev could not overcome these difficulties and returned to Kazan without completing his studies. Undoubtedly, a longer process and more thorough preparation were required to gain artistic independence.

\section{Summary}

Thus, a professional training of Tatar composers had a number of difficulties related to creative and methodological issues. However, they still achieved good results. Many works written in the studio are included in the "golden fund" of the national musical classics. Subsequently, the composers mastered different genres, improving their professional skills.

\section{Acknowledgements}

The work is performed according to the Russian Government Program of Competitive Growth of Kazan Federal University.

\section{References}

[1] Egorova N., Samigullina R., Yavgildina Z. Features of musical enlightenment activity in Russia in the 30ies of $\mathrm{xx}$ century // The Turkish Online Journal of Design, Art and Communication (TOJDAC). November 2016. Vol. 6, Special Edition. P. 2270-2275. [2] Faizrakhmanova L. T., Kovrikova E. V. The ethnoconfessional relations in the context of culture and education (Kazan province, XVIII - beginning of XX century) // BylyeGody, 2017. Vol. 43, Is. 1. P. 30-38.

[3] Karkina S. V., Fajzrahmanova L.T. Tradition and modern experience of the Kazan piano school in the aspect of subject-oriented approach //The Turkish Online Journal of Design, Art and Communication (TOJDAC). November 2016. Vol. 6, Special Edition.P. 2451-2456.

[4]MartynovaY.A., MartynovD.E. Specific features of music education in soviet Russia in 1918 to 1922 (in terms of social and cultural environment in Kazan) // The Turkish Online Journal of Design, Art and Communication (TOJDAC). November 2016. Vol. 6, Special Edition.P. 2783-2787.

[5]KhurmatullinaR.C, SalpykovaI.M. Tatar folklore in the creative work of composer Rafael Belyalov // Middle-East Journal of Scientific Research, 2014. Vol.19, Is.1.P.29-41.

[6] Kovrikova E., Nurgayanova N. Spiritual musical and cultural traditions of the tatars in the music of ShamilSharifullin / 3rd International Multidisciplinary Scientific Conference on Social Sciences and Arts SGEM 2016. Aug 24-31, 2016. Book 4, Vol. 3. P.6370.

[7]SalihovA.N., Dulat-Aleev V. R. Factors of Increasing Communicative Potential of Musical 2366
Creations in Terms of Intercultural Communication (Evidence from the Music of Tatar Composers) // International journal of humanities and cultural studies. August 2016. Special Is.P.350-355.

[8] MaklyginA.L. Musical Cultures of the Middle Volga Region: Professionalism Formation. - Kazan: Kazan State Conservatory, 2000. - 309 p.

[9] MaklyginA.L. Litinsky and Leman: to the Problem of Teaching "National Composers" // Journal of the Society of Music Theory: Issue 2016/3 (15). - P. 3036.

[10] Archive of the Moscow Conservatory. F. 658. In. 15.Ed. 1953.

[11] Russian State Archive of Literature and Art (RGALI). F. 658. In. 2.Ed. 2. L. 23.

[12] RGALI. F. 658. In. 2.Ed. 27. L. 6.

[13] National Archive of the Republic of Tatarstan. F. 128. In. 1.Ed. No. 2129. Volume 2. L. 147.

[14] G.I. Litinsky. Life. Art. Pedagogy. Collection of Articles, Memoirs, Documents / Edited by A. Grigoryeva. - M., 2001. - 360 p.

[15] SalikhovaL.I. Problems of national opera genre formation in 1930's (on the example of Tatar musical culture) // Social Sciences (Pakistan), 2015. Vol. 10, Is. 6. P. $990-995$. 